\title{
IFN-gamma signaling in the central nervous system controls the course of experimental autoimmune encephalomyelitis independently of the localization and composition of inflammatory foci
}

Eunyoung Lee ${ }^{1,2}$, Sarah Chanamara', David Pleasure ${ }^{1,3}$ and Athena M Soulika ${ }^{1,2^{*}}$

\begin{abstract}
Background: Murine experimental autoimmune encephalomyelitis (EAE), a model for multiple sclerosis, presents typically as ascending paralysis. However, in mice in which interferon-gamma (IFN $\gamma$ ) signaling is disrupted by genetic deletion, limb paralysis is accompanied by atypical deficits, including head tilt, postural imbalance, and circling, consistent with cerebellar/vestibular dysfunction. This was previously attributed to intense cerebellar and brainstem infiltration by peripheral immune cells and formation of neutrophil-rich foci within the CNS. However, the exact mechanism by which IFNy signaling prohibits the development of vestibular deficits, and whether the distribution and composition of inflammatory foci within the CNS affects the course of atypical EAE remains elusive.
\end{abstract}

Methods: We induced EAE in IFN $\gamma-/$ - mice and bone marrow chimeric mice in which IFNyR is not expressed in the CNS but is intact in the periphery (IFNy $R^{\mathrm{CNS}} \mathrm{KO}$ ) and vice versa (IFNy ${ }^{\text {peri }} \mathrm{KO}$ ). Blood-brain barrier permeability was determined by Evans blue intravenous administration at disease onset. Populations of immune cell subsets in the periphery and the CNS were quantified by flow cytometry. CNS tissues isolated at various time points after EAE induction, were analyzed by immunohistochemistry for composition of inflammatory foci and patterns of axonal degeneration.

Results: Incidence and severity of atypical EAE were more pronounced in IFN $\mathrm{R}^{\mathrm{CNS}} \mathrm{KO}$ as compared to IFNyR ${ }^{\text {peri }} \mathrm{KO}$ mice. Contrary to what we anticipated, cerebella/brainstems of IFNyR ${ }^{\mathrm{CNS}} \mathrm{KO}$ mice were only minimally infiltrated, while the same areas of IFN $\gamma \mathrm{R}^{\text {peri }} \mathrm{KO}$ mice were extensively populated by peripheral immune cells. Furthermore, the

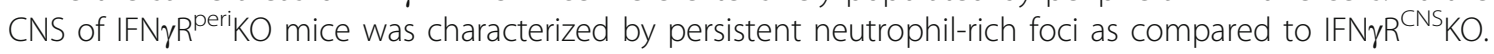
Immunohistochemical analysis of the CNS of IFN $\gamma-/$ - and IFNyR chimeric mice revealed that IFN $\gamma$ protective actions are exerted through microglial STAT1.

Conclusions: Alterations in distribution and composition of CNS inflammatory foci are not sufficient for the onset of atypical EAE. IFN $\gamma$ dictates the course of neuroinflammatory disorders mainly through actions exerted within the CNS. This study provides strong evidence that link microglial STAT1 inactivation to vestibular dysfunction.

Keywords: microglia, cerebellum, brainstem, EAE, IFNY, STAT1, inflammation

\footnotetext{
* Correspondence: athena.soulika@ucdmc.ucdavis.edu

${ }^{1}$ Institute for Pediatric Regenerative Medicine, Shriners Hospitals for Children

Northern California, Sacramento, California, USA, 95817

Full list of author information is available at the end of the article
} 


\section{Introduction}

Experimental autoimmune encephalomyelitis (EAE) is the most commonly used animal model for multiple sclerosis (MS). Similar to MS, animals with EAE exhibit activation of immune cells in peripheral immune organs, migration of these cells into the CNS, and establishment of multifocal inflammation, demyelination and damage to neurons and axons. Cumulative axonal loss eventually leads to severe and permanent neurological deficits $[1,2]$. In classical EAE, most neurological deficits are attributable to spinal cord lesions. Interestingly, mice in which IFN $\gamma$ signaling has been genetically disrupted (IFN $\gamma-/-$, or IFN $\gamma \mathrm{R}-/$ - mice), also show evidences of cerebellar/ vestibular dysfunction, deficits that are regarded as atypical EAE features. Such deficits in MS patients are associated with poor prognosis [3-5]. This atypical EAE course is behaviorally characterized by deficits such as axial rotation, circling behavior, and balance impairment. In this study we sought to determine the mechanisms by which interrupted IFN $\gamma$ signaling leads to this atypical course.

IFN $\gamma$ is a multifunctional cytokine that is involved in the initiation and establishment of inflammation, and participates in both innate and adaptive immune responses. T and NK cells are the main sources of IFN $\gamma$ $[6,7]$ but it can be induced in many other cell types including neurons $[8,9]$. IFN $\gamma$ is also crucial for the resolution of inflammation by inducing apoptosis of activated lymphocytes, supporting Treg function, and restricting the development of $\mathrm{T}$ cell subsets associated with autoimmunity $[10,11]$. Thus, the exacerbation of neurological disability in animals with EAE in the absence of IFN $\gamma$ or its receptor has been attributed in the past to uncontrollable expansion of pathogenic immune cells in the periphery [12-14].

However, IFN $\gamma$ has yet-to-be fully defined actions on neurons, astrocytes, oligodendrocytes and microglia, all of which express IFN $\gamma \mathrm{R}[8,15-20]$. It is possible that IFN $\gamma$ acts as a disease-limiting agent within the CNS but not in peripheral immune tissues. This would explain why peripherally administered IFN $\gamma$ has no effect on the course of EAE, while intraventricularly administered IFN $\gamma$ alleviates or resolves the neurological deficits [21-23].

Alternatively, the protective effect of IFN $\gamma$ signaling in EAE may be exerted both in peripheral immune cells and within the CNS $[22,24,25]$. Passively transferred EAE is characterized by increased cerebellar/brainstem infiltration and atypical neurological deficits when IFN $\gamma$ signaling is disrupted in either the recipient mouse or the donor cells [24]. One drawback of passively transferred EAE, however, is that immune cells from the recipient animal are also activated and migrate into the
CNS parenchyma along with those of the donor [26,27], thus making it challenging to dissociate peripheral from CNS events. Furthermore, passively transferred IFN $\gamma-/$ cells will also perturb IFN $\gamma$ induced signaling in CNS resident cells; this is because, in EAE, infiltrating immune cells are the major IFN $\gamma$ source in the CNS. For these reasons, it remains unclear whether the development of atypical deficits in the absence of IFN $\gamma$ is due to effects on peripheral immune cells before or after they enter the CNS, or directly on CNS resident cells.

Finally, although in EAE mice without IFN $\gamma$ signaling, infiltration of the cerebellum or brainstem by peripheral immune cells has been considered sufficient for the development of atypical deficits, EAE-susceptible mouse strains with intact IFN $\gamma$ signaling show infiltration of these areas but never develop atypical deficits [28-30].

In this study, we re-visited the role(s) of IFN $\gamma$ signaling in the genesis of atypical EAE. We initially characterized the disease process in IFN $\gamma-/$ - mice. Then, to differentiate between peripheral and CNS-restricted roles of IFN $\gamma$ signaling, we constructed irradiation bone marrow chimeric mice in which IFN $\gamma \mathrm{R}$ was expressed in radioresistant CNS cells but not in radiosensitive peripheral immune cells or vice versa.

Our data shows that active EAE induction in mice lacking IFN $\gamma \mathrm{R}$ in the CNS results in more frequent and more severe atypical neurological deficits compared to mice lacking IFN $\gamma \mathrm{R}$ in peripheral immune cells. This difference in incidence of atypical EAE was not attributable to more extensive cerebellar infiltration, preferential recruitment of pathogenic immune cell subsets within the CNS, or increased axonopathy. Instead, our data are consistent with the hypothesis that IFN $\gamma$ exerts protective actions against vestibular/brainstem/cerebellar dysfunction in EAE via activation of the microglial IFN $\gamma$ R-STAT1 pathway.

\section{Methods}

Mice

IFN $\gamma$-/- and IFN $\gamma$ RKO, C57BL/6 (C57BL/6CD45.2) mice and B6.SJL-Ptprc ${ }^{a}$ Pepc $^{b} /$ BoyJ (C57BL/6CD45.1) were purchased from Jackson Laboratory. Both males and females (matched per experiment) were used. Mice were housed in a pathogen-free facility. All experimental protocols were approved by the Institutional Animal Care and Use Committee of the University of California, Davis.

\section{Generation of bone marrow chimeras (BMC)}

Recipient mice (6 weeks old) were irradiated with 950 rads (Cs-137 source, MK1-30 irradiator, J.L Shepherd and Assoc.) 18 to 24 hours before bone marrow transfer, and treated with antibiotic water (sulfamethoxazole, Hi- 
Tech Pharmacal) for two weeks thereafter. Bone marrow cells were harvested from femurs and tibias of donor mice and red blood cells were lysed with ACK solution (Quality Biological) for $3 \mathrm{~min}$ at $37^{\circ} \mathrm{C}$. T cells were removed by complement mediated lysis, by resuspending bone marrow cells at a concentration of $10^{7}$ cells/ $\mathrm{mL}$ in Cytotoxic media, RPMI-1640 containing $25 \mathrm{mM}$ Hepes buffer and $0.3 \%$ bovine serum albumin, followed by successive incubation with Thy1.2 antibody (1:500, CEDARLANE) at $4^{\circ} \mathrm{C}$ for $30 \mathrm{~min}$ and Low Tox $\mathrm{M}$ rabbit complement $\left(1: 10\right.$, CEDARLANE) at $37^{\circ} \mathrm{C}$ for $30 \mathrm{~min}$. Cells were resuspended in PBS and counted. Ten million bone marrow cells in $150 \mu \mathrm{l}$ were injected into the recipient mice via tail vein injection the day after lethal irradiation. EAE was induced 6 to 8 weeks post bone marrow reconstitution. BMC constructed are described in Table 1.

\section{EAE induction}

EAE was induced as previously described [1]. Briefly, 300 $\mu \mathrm{g}$ of rodent MOG peptide (amino acids 35-55, New England Peptides) in CFA containing $5 \mathrm{mg} / \mathrm{ml}$ killed Mycobacterium tuberculosis (Difco) were administered subcutaneously in the flank to age-matched (11-14 weeks-old) mice on day 0 . Non-irradiated mice received $200 \mathrm{ng}$ of pertussis toxin and bone marrow chimeras 50 ng of pertussis toxin intraperitoneally on days 0 and 2 . Both classical and atypical neurological deficits were evaluated daily until day 35 post immunization (pi). Classic neurological deficits were graded as follows: limp tail or waddling gait $=1$; limp tail and waddling gait $=2$; single limb paresis and ataxia 2.5; double limb paresis $=3$; single limb paralysis and paresis of second limb $=3.5$; full paralysis of 2 limbs $=4$; moribund $=4.5$; and death $=5$ $[1,31]$. Atypical neurological deficits were graded as previously described [32] with slight modifications: Mild head tilting $=1$, severe head tilting $=2$, body tilting $=3$, involuntary and continuous axial rotation $=4$.

\section{Mapping areas of blood brain barrier breakdown by Evans blue}

Mice were intravenously injected with $200 \mu \mathrm{l}$ of $2.5 \%$ Evans blue (Sigma) in saline. Ninety minutes later, mice

Table 1 Irradiation bone marrow chimeric mice (BMC)

\begin{tabular}{|c|c|c|}
\hline Donor mice & Recipient mice & BMC mice \\
\hline IFNyRKO-CD45.2 & IFNyRKO-CD45.2 & IFN $\gamma$ RKO-chimeras \\
\hline$\overline{C 57 B L / 6-C D 45.1}$ & IFNyRKO-CD45.2 & IFN $\gamma R^{C N S} K O$ \\
\hline C57BL/6-CD45.1 & C57BL/6-CD45.2 & WT-chimeras \\
\hline IFNyRKO-CD45.2 & C57BL/6-CD45.1 & IFNyR $R^{\text {peri }} K O$ \\
\hline
\end{tabular}

Radiosensitive (peripheral immune) cells carry the genotype of donor mouse, while radioresistant cells (all parenchymal cells including the CNS) carry the genotype of the recipient mouse. were anesthetized by intraperitoneal injection of ketamine $(150 \mathrm{mg} / \mathrm{kg})$ and xylazine $(16 \mathrm{mg} / \mathrm{kg})$ and intracardially perfused with ice cold PBS, followed by $4 \%$ paraformaldehyde (PFA) in PBS. The brains and spinal cords were harvested, post-fixed in $4 \%$ PFA overnight at $4{ }^{\circ} \mathrm{C}$. The next day, tissues were sectioned at sites of Evans blue staining and photographed using the Zeiss SteREO Lumar.V12.

\section{Isolation of leukocytes from mouse spleen/lymph nodes and CNS}

Mice sacrificed by $\mathrm{CO}_{2}$ asphyxiation were perfused with ice cold PBS. Spleens and draining lymph nodes were harvested, combined, minced in PBS, and pushed with the back of a syringe plunger through a $40 \mu \mathrm{m}$ mesh. Red blood cells were lysed with ACK solution (Quality Biologicals). Brains and spinal cords were minced, digested at $37^{\circ} \mathrm{C}$ for $30 \mathrm{~min}$ in PBS containing 0.04 units of Liberase R1 (Roche) and $10 \mu \mathrm{g}$ of DNase I (Roche) per $\mathrm{ml}$. Softened fragments were pushed through a $100 \mu \mathrm{m}$ mesh. CNS infiltrating cells were isolated via a discontinuous 40/70\% (v/v) Percoll gradient (GE Healthcare).

\section{Ex vivo $\mathrm{T}$ cell responses}

Mixed splenocytes and lymph node cells were cultured in $200 \mu \mathrm{l}$ of RPMI 1640 containing 10\% FBS, 2 mM Lglutamine, $0.1 \mathrm{mM}$ nonessential amino acids, $100 \mathrm{U}$ penicillin-streptomycin, $50 \mu \mathrm{M}$ 2-mercaptoethanol, and $1 \mathrm{mM}$ sodium pyruvate with or without $50 \mu \mathrm{g} / \mathrm{ml} \mathrm{MOG}$ peptide (amino acids 35-55) for 24 hrs. The cells were incubated with brefeldin A (GolgiPlug, BD Bioscience) for the last $5 \mathrm{hr}$.

\section{Flow cytometry}

Mixed splenocytes and lymph node cells were immunostained immediately after isolation or after the 24 hour culture described above. CNS mononuclear cells were immunostained after incubation at $37^{\circ} \mathrm{C}$ for 3 hours in RPMI 1640 containing 10\% FBS, 2 mM L-glutamine, 0.1 $\mathrm{mM}$ nonessential amino acids, $100 \mathrm{U} / \mathrm{mL}$ penicillinstreptomycin, $50 \mu \mathrm{M}$ 2-mercaptoethanol, and $1 \mathrm{mM}$ sodium pyruvate in the presence of brefeldin A. Immediately prior to immunostaining, Fc receptors were blocked for $10 \mathrm{~min}$ with anti-CD16/32. Neutrophils were identified by Fluorescein Isothiocyanate (FITC)labeled anti-mouse Ly-6G and Pe-Cy ${ }^{\mathrm{TM}} 7$-labeled antimouse Gr1 (BD pharmingen), macrophages or microglia by Phycoerythrin (PE)-labeled anti-mouse CD45, BD pharmingen and eFlour ${ }^{\circledR} 450$-labeled anti-mouse CD11b (eBioscience), and dendritic cells by Allophycocyanin (APC)-labeled anti-mouse CD11c (BD Pharmingen). To distinguish donor cells from recipient cells, cells were co-stained with FITC labeled anti-mouse CD45.2 (BD 
pharmingen) and APC-labeled anti-mouse CD45.1 (eBioscience). For $\mathrm{T}$ helper (Th) and $\mathrm{T}$ cytotoxic $(\mathrm{Tc})$ cell subset analysis, cells were stained with Pacific Blue (PB)-labeled anti-mouse CD4 and FITC-labeled antimouse CD8a (BD pharmingen), fixed, permeabilized using the Cytofix/Cytoperm Plus Kit (BD pharmingen) according to the manufacturer's protocol, and intracellularly stained with APC-labeled anti-mouse IFN $\gamma, \mathrm{PE}$ labeled anti-mouse IL17 and Pe-Cy ${ }^{\mathrm{TM}} 7$-labeled antimouse TNF $\alpha$ (BD pharmingen). Th1: CD4+IFN $\gamma+$, Th17: CD4+IL17+, Th1/17: CD4+IFN $\gamma+$ IL17+ Tc1: CD8 +IFN $\gamma+$, Tc17: CD8+IL17+, Tc1/17: CD8+IFN $\gamma+$ IL17+. For regulatory $\mathrm{T}$ lymphocyte (Treg, CD4+CD25+Foxp3 $+)$ analysis, cells were stained with PB-labeled antimouse CD4 and APC-labeled anti-mouse CD25 (eBioscience) with Fc receptor blocker, fixed, and permeabilized using the Fixation \& Permiabilization kit (eBioscience), then intracellularly stained with PElabeled anti-mouse/rat Foxp3 (eBioscience). Immunostained cells were analyzed using a Cyan FACS (Dako Cytomation).

\section{Immunohistology of spinal cord and cerebellum/ brainstem}

Mice were anesthetized and brains and spinal cords tissues were harvested as described in the "Mapping areas of blood brain barrier breakdown by Evans blue" section. Harvested tissues were fixed overnight in $4 \%$ PFA, immersed in $30 \%$ sucrose for 48 hours at $4^{\circ} \mathrm{C}$ and embedded in cryostat mounting media (Tissue-Tek OCT, Sakura Finetek). Tissues were coronally or sagittally sectioned at $10 \mu \mathrm{m}$ thickness. Sections were airdried at RT for $30 \mathrm{~min}$, rinsed briefly with PBS, and blocked with $10 \%$ of donkey or goat serum, depending on the secondary antibody used. Some sections were blocked with antibody diluent (IHC-Tek ${ }^{\mathrm{TM}}$ ). Sections were incubated with primary antibodies listed in Table 2 overnight at $4^{\circ} \mathrm{C}$ and next day, with fluorescently conjugated secondary antibodies to DyLight ${ }^{\mathrm{TM}} 488$ or DyLight ${ }^{\mathrm{TM}} 549$ (Jackson ImmunoResearch) for an hour at RT. Between each step, the sections were washed repeatedly with PBS for 5 min period to reduce background. Nuclei were visualized by DAPI counterstain. Fluorescent images were analyzed by confocal microscopy (Nikon A1). Microscopic fields were photographed with $20 \times$ or $40 \times$ objectives mounted on a Nikon A1 scanning confocal microscope using the Nikon NIS-Elements AR 3.10 software. Exposure was adjusted per staining for all groups of mice using Adobe Photoshop.

Quantification of SMI32+ axons, demyelinating foci, CD45R + cells or IL4+ cells

Fields encompassing the whole spinal cord or cerebellum were photographed using a $20 \times$ objective mounted
Table 2 Primary antibodies used for immunohistochemistry

\begin{tabular}{ll}
\hline Antigen & Antibody \\
\hline Ly6G & FITC-conjugated rat anti-mouse Ly6G \\
& BD Pharmingen (Cat\#551460), 1:100 \\
\hline BA1 & Rabbit polyclonal anti-IBA1 \\
& Wako (Cat\#019-19741), 1:1000 \\
\hline CD11b & Rat anti-mouse CD11b \\
& BD Pharmingen (Cat\#550282), 1:100 \\
\hline CD4 & Rat anti-mouse CD4 \\
& BD Pharmingen (Cat\# 550280), 1:100 \\
\hline CD45.1 & PE-conjugated mouse anti-mouse CD45.1 \\
& eBioscience (Cat\#12-0453-82), 1:100 \\
\hline CD45.2 & PE-conjugated mouse anti-mouse CD45.2 \\
& BD Pharmingen (Cat\# 560695), 1:100 \\
\hline CD45.2 & FITC-conjugated mouse anti-mouse CD45.2 \\
& eBioscience (Cat\#11-0454-85) \\
\hline SMI32 & Mouse anti-mouse NF-H \\
& Covance (Cat\# SMI-32R), 1:1000 \\
\hline STAT1 & Rabbit polyclonal anti-human STAT1 \\
& Santa Cruz (Cat\# SC592), 1:100 \\
\hline CD45R & PE-Texas Red rat anti-mouse CD45R/B220 \\
& BD Pharmingen (Cat\# 551489), 1:100 \\
\hline IL4 & Goat anti-mouse IL4 \\
& R\&D (Cat\# AF-404-NA) \\
\hline MBP & Rat anti-bovine myelin basic protein \\
& Novus biologicals (Cat\# NB600-717) \\
\hline
\end{tabular}

on a Nikon laser scanning confocal microscope, and images were tiled together using the Nikon NIS-Elements software. All SMI32+ axons in the white matter of spinal cords and cerebella isolated from mice with EAE were counted with the aid of NIH ImageJ software. Demyelinating foci (absence of MBP staining) were traced in the white matter of spinal cords and cerebella isolated from mice with EAE were measured with the aid NIS-Elements software. Total white matter areas were measured in the cross-sections of cerebella or spinal cords and were used for normalization in the quantification of SMI32+ axons and demyelinating foci. Total spinal cord or cerebellum cross-section areas were used for normalization when quantifying CD45R+ or IL4+ cells. Three $10 \mu \mathrm{m}$ sections (40-50 $\mu \mathrm{m}$ apart from each other) were counted per animal, $n=4$ animals. To determine statistical significance between the chimeric groups a Kruskal-Wallis test with post-hoc Mann-Whitney $U$ tests with Bonferroni correction was performed.

\section{Numbers of mice used in the study Flow cytometry}

WT and IFN $\gamma$-/-: To calculate significance, p-values were derived using the Mann-Whitney $U$ test with Bonferroni correction. The experiment was repeated 2-3 times, employing 3 mice per experiment for a total of 6 9 mice per time-point per group. 
IFN $\gamma$ RKO chimeras: To determine statistical significance between the chimeric groups a Kruskal-Wallis test with post-hoc Mann-Whitney U tests with Bonferroni correction was performed. The experiment was repeated 3 times employing 2 mice per experiment for a total of 6 mice per time-point per group.

\section{Immunohistochemistry}

The experiment was repeated 2-3 times, employing 2-3 mice per experiment for a total of 4-9 mice per timepoint per group.

\section{Results}

Atypical neurological deficits initiate in the absence of IFN $\gamma$ signaling in the CNS

Clinical course in wild type and IFN $\gamma$-/- mice

Classic neurological deficits of EAE (ascending paralysis) appeared both in IFN $\gamma$-/ - and wild-type (WT) controls on or around day 10 post-immunization (pi). During the chronic phase of EAE (post day 21), WT mice improved slightly, but IFN $\gamma-/$ - mice continued to display severe typical symptoms (Figure 1A). Atypical symptoms such as head tilting, continuous axial rotation, and leaning towards one side developed only in IFN $\gamma$-/ - mice, starting on or a few days after the onset of the classic EAE course (Figure 1B).

\section{Clinical course in IFNYRKO chimeras}

Classic neurological deficits appeared in all irradiation bone marrow chimeric groups on or around day $11 \mathrm{pi}$. IFN $\gamma$ RKO-chimeras, IFN $\gamma \mathrm{R}^{\mathrm{CNS}} \mathrm{KO}$ mice, and WT-chimeras showed classic deficits of similar severity throughout the course of their illness, while IFN $\gamma \mathrm{R}^{\text {peri }} \mathrm{KO}$ mice displayed slightly milder disease severity during the chronic phase of EAE (Figure 1C). Atypical neurological deficits developed in $88 \%$ of IFN $\gamma \mathrm{RKO}$-chimeras on day $14.8 \pm 0.5$ (means \pm SEM) but were not present in WTchimeras (Figure 1D). Interestingly, EAE induction in mice without IFN $\gamma$ signaling in the $\mathrm{CNS}$ (IFN $\gamma \mathrm{R}^{\mathrm{CNS}} \mathrm{KO}$ ) resulted in the development of more severe and more frequent atypical disease, that had an earlier onset than mice without IFN $\gamma$ signaling in the periphery

\section{Classic}

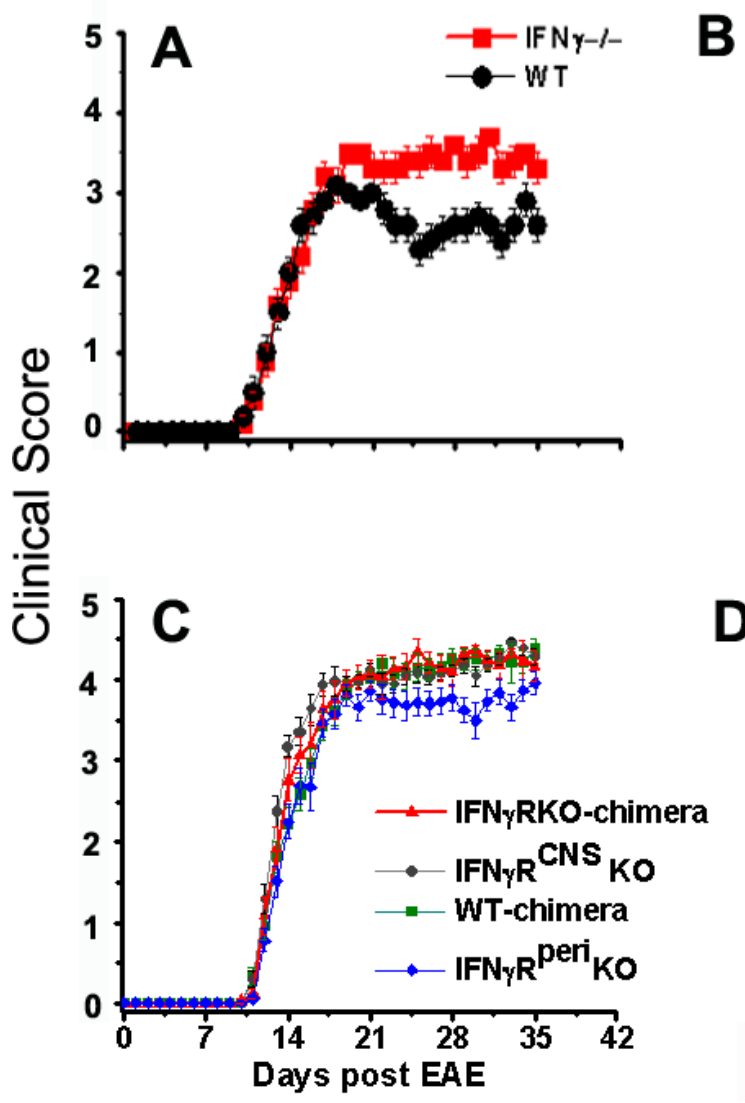

\section{Atypical}

\begin{tabular}{|c|c|c|}
\hline & $\begin{array}{c}\text { Day of onset } \\
( \pm \text { SEM) }\end{array}$ & $\begin{array}{c}\% \\
\text { incidence }\end{array}$ \\
\hline $\begin{array}{c}\text { IFN } \gamma-1- \\
(\mathrm{n}=51)\end{array}$ & $17( \pm 0.6)$ & 88 \\
\hline $\begin{array}{c}\text { WT control } \\
(\mathrm{n}=54)\end{array}$ & $\mathrm{n} / \mathrm{a}$ & 0 \\
\hline
\end{tabular}

\begin{tabular}{|c|c|c|c|}
\hline & $\begin{array}{l}\text { Days of onset } \\
\quad( \pm \text { SEM) }\end{array}$ & $\begin{array}{c}\% \\
\text { incidence }\end{array}$ & $\begin{array}{c}\text { Cumulative } \\
\text { severity } \\
( \pm \text { SEM })^{\star *}\end{array}$ \\
\hline $\begin{array}{c}\text { IFNүRKO } \\
\text { chimera ( }(n 35)\end{array}$ & $14.8( \pm 0.5)$ & 88 & $11.8( \pm 1.7)$ \\
\hline 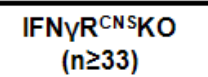 & $14.9( \pm 0.5)$ & 78 & $5.3( \pm 1.1)$ \\
\hline $\begin{array}{c}\text { IFNYR periKO } \\
(\mathrm{n} \geq 31)\end{array}$ & $17.7( \pm 1.4)$ & 31 & $1.4( \pm 0.4)$ \\
\hline $\begin{array}{c}\text { WT chimera } \\
(n \geq 27)\end{array}$ & $\mathrm{n} / \mathrm{a}^{*}$ & 0 & $\mathrm{n} / \mathrm{a}^{*}$ \\
\hline
\end{tabular}

Figure 1 EAE course in IFN $\gamma-/$ - and WT mice and IFN $\gamma$ R-KO chimeras. Classic (A and C) and atypical deficits (B and D) were monitored and documented daily as described in the methods. Data are represented as means \pm SEMs (A and B, n=51-54, C and D, $n=13-20$ ). ${ }^{*} n / a$ : not applicable, ${ }^{* *}$ Average cumulative atypical score of mice with EAE up to day 20 post-immunization. 
(IFN $\gamma \mathrm{R}^{\text {peri }} \mathrm{KO}$ ): $78 \%$ of IFN $\gamma \mathrm{R}^{\mathrm{CNS}} \mathrm{KO}$ (day of onset $14.9 \pm$ 0.5 , and average cumulative score $5.3 \pm 1.1$ ) versus $31 \%$ of IFN $\gamma \mathrm{R}^{\text {peri }} \mathrm{KO}$ (day of onset $17.7 \pm 1.4$, and average cumulative score $1.4 \pm 0.4$ ) developed atypical EAE (Figure 1D).

\section{Peripheral immune responses and CNS leukocyte accumulation are not correlated with the incidence of atypical symptoms}

To detect possible associations between atypical disease and activation of peripheral immune cells and/or preferential recruitment of immune subsets into the CNS, we isolated cells from lymphoid organs and from Percollfractionated pooled brain and spinal cord of the various groups of mice at the peak of disease (days 14-21 pi) and analyzed them by flow cytometry as described in the methods.

\section{IFN $\gamma-/-/ W T$}

Significantly increased numbers of peripheral MOG-specific Th17 cells were generated (Additional file 1) in IFN $\gamma$-/- mice compared to WT controls only on day 14 pi $(\mathrm{p}=0.001)$. As expected, CD4+IFN $\gamma+(\mathrm{Th} 1) \mathrm{CD} 4$ + IFN $\gamma+$ IL17+ (Th1/17), CD8+IFN $\gamma+(\mathrm{Tc} 1)$ and CD8 + IFN $\gamma+$ IL $17+(\mathrm{Tc} 1 / 17)$ cells were only observed in WT controls and not in IFN $\gamma$-/- mice. No other statistically significant differences between the two groups were observed in the numbers of immune cell subsets in peripheral lymphoid organs (Additional file 1). In the CNS, the numbers of neutrophils, total CD4+ T and Th17 cells were significantly increased in IFN $\gamma-/$ - mice as compared to WT controls (Figure 2 A-C). These observations suggest that global absence of IFN $\gamma$ facilitates the accumulation of neutrophils and CD4+ T cells in the CNS, in agreement with previous studies [12,24,33]. Furthermore, the increased numbers of Th17 cells in the CNS of IFN $\gamma$-/- mice may imply preferential migration and/or (re)polarization of these cells within the CNS; however, the decreased ratios of Tregs:Th17 in the CNS of IFN $\gamma-/$ - mice as compared to WT mice ( $\mathrm{p}=$ 0.007, Additional file 1) imply that in the absence of IFN $\gamma$, Tregs may not efficiently control the Th17induced neurotoxicity [34].

\section{IFN $\gamma R K O$ chimeras}

To determine the degree of chimerism, we used CD45.1/CD45.2 allelic markers to identify host versus donor infiltrating cells. All of the chimeric mice exhibited $85-95 \%$ of donor cells in the periphery. Mice from each chimeric group were randomly selected, sacrificed 6-8 weeks post reconstitution and mononuclear cells were isolated from the CNS. We found that in the CNS of chimeric mice, microglia were typically $85-95 \%$ of recipient origin (data not shown). We were not able to collect such data for IFN $\gamma$ RKO-chimeric mice since both the recipient and donor cells carry the CD45.2 allele.
There were no significant differences between the four groups of chimeric mice in the peripheral immune cell subsets examined on days 14 and 21 pi. However, by day 21 , IFN $\gamma$ RKO chimeric mice tended to exhibit more TNF $\alpha$-producing cells in the periphery as compared to the three other groups. In the CNS, the total numbers of CD4+ and CD8+ T cells and microglia of the various groups of chimeric mice were also comparable (Additional file 1). As in WT-mice, WT-chimeras and IFN $\gamma$ R${ }^{\text {peri }} \mathrm{KO}$ mice tended to exhibit higher Treg:Th17 ratios compared to IFN $\gamma \mathrm{RKO}$-chimeras and IFN $\gamma \mathrm{R}^{\mathrm{CNS}} \mathrm{KO}$ mice; however these differences did not reach statistical significance. In addition, in the CNS of the IFN $\gamma R^{\text {peri }} \mathrm{KO}$ mice CD8+ $\mathrm{T}$ cells were elevated but this again did not reach statistical significance (Additional file 1).

Nevertheless, the differential expression of IFN $\gamma$ R did influence the composition of the infiltrating immune cells. On day 14 , IFN $\gamma \mathrm{R}^{\text {peri }} \mathrm{KO}$ mice had statistically significantly lower numbers of Th17 in the CNS compared to the rest of the chimeric groups (Figure 2F), which was not due to defective Th17 cell generation in the periphery of these mice (Additional file 1). However, by day 21 all groups exhibited similar numbers of Th17 cells within the CNS.

Although there was no difference between the chimeric groups in the numbers of neutrophils (Ly6G+GR1 + ) within the CNS at disease onset (day 14 pi), a week later (day $21 \mathrm{pi}$ ), these numbers were significantly higher in IFN $\gamma \mathrm{RKO}$-chimeras and IFN $\gamma \mathrm{R}^{\text {peri }} \mathrm{KO}$ mice compared to WT-chimeras and IFN $\gamma \mathrm{R}^{\mathrm{CNS}} \mathrm{KO}$ mice (Figure 2D). Thus, the migration of neutrophils into the CNS was IFN $\gamma$-independent, but their maintenance in (or continuous migration to) the CNS was facilitated by the absence of IFN $\gamma$ signaling in peripheral immune cells.

$B$ cells have been implicated in the generation of atypical EAE [35]. B cells were quantified by immunohistochemistry using an anti-CD45R antibody. As shown in additional file 1 , on day 14 , B cells numbers were not statistically significantly different between the chimeric groups. On day 21 however, B cells number were statistically significantly decreased in IFN $\gamma \mathrm{R}^{\mathrm{CNS}} \mathrm{KO}$ and increased in IFN $\gamma \mathrm{R}^{\text {peri }} \mathrm{KO}$ compared to WT-chimeras and IFN $\gamma \mathrm{RKO}$-chimeras.

Expression of IFN $\gamma \mathrm{R}$ in the CNS, independent of its expression in the periphery, enhanced CNS accumulation of infiltrating macrophages [WT-chimeras (CD11b + CD 45.1 $1^{\text {hi }}$ Ly6G-) and IFN $\gamma R^{\text {peri }}$ KO (CD11b $+C D 45.2^{\text {hi- }}$ Ly6G-)] both on days 14 and 21 (Figure 2E), suggesting that macrophage migration cues are regulated by IFN $\gamma$ induced events within the CNS (e.g. chemokine expression by CNS resident cells).

Furthermore, IFN $\gamma \mathrm{R}^{\mathrm{CNS}} \mathrm{KO}$ mice showed a similar composition of infiltrating cells (neutrophils, $\mathrm{T}$ cell subsets) to WT-chimeras. These two groups exhibited 


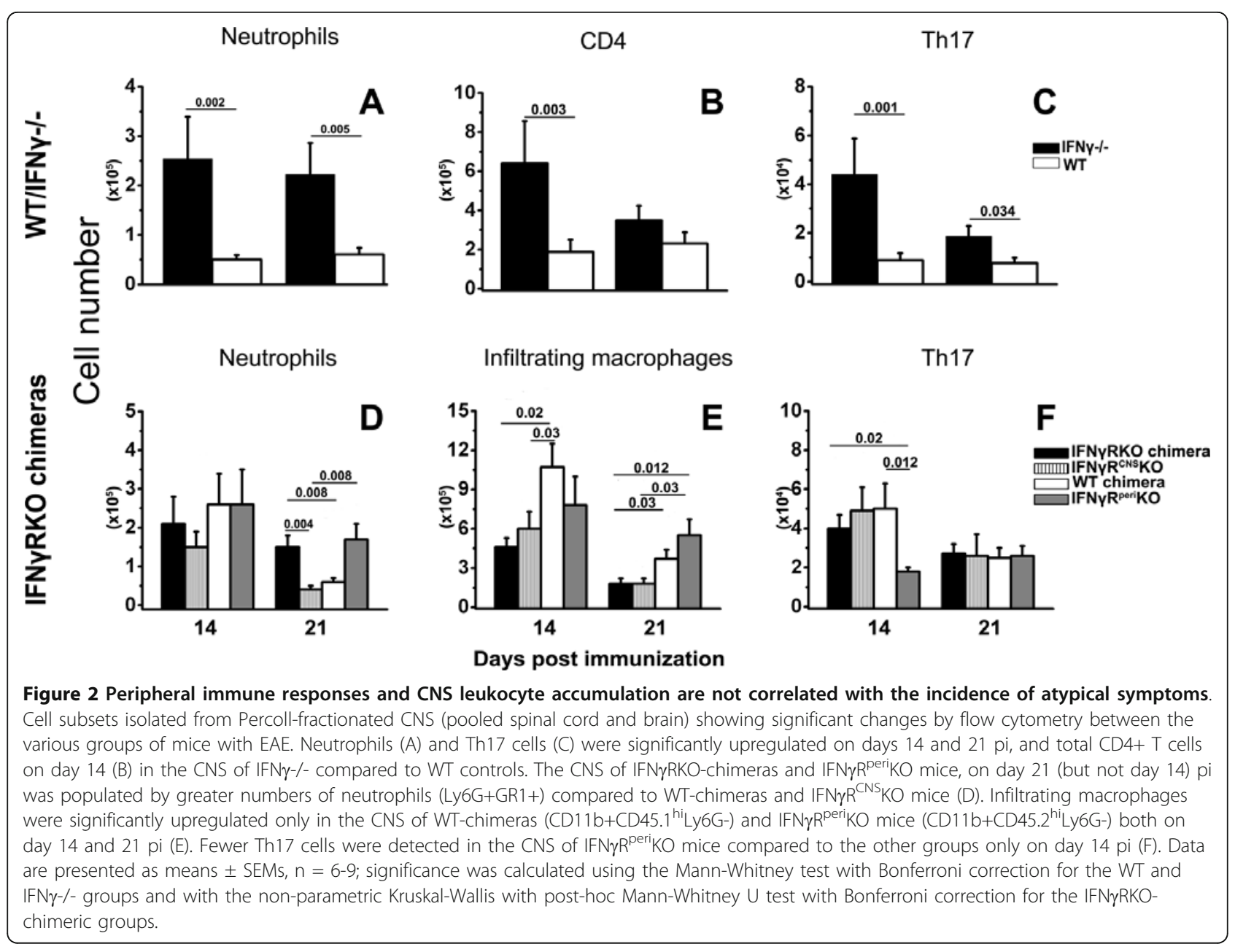

differences in infiltrating macrophages but only on day 14: WT-chimeras showed increased numbers of infiltrating macrophages compared to both IFN $\gamma \mathrm{R}^{\mathrm{CNS}} \mathrm{KO}$ and IFN $\gamma R K O$-chimeras (Figure 2). On day 21, increased numbers of macrophages observed in WT-chimeras were statistically significantly different than those in IFN $\gamma$ RKO chimeras but did not reach statistical significance compared to those in IFN $\gamma \mathrm{R}^{\mathrm{CNS}} \mathrm{KO}$ mice. Macrophages showed the same trends in WT-chimeras and IFN $\gamma \mathrm{R}^{\text {peri }} \mathrm{KO}$ mice.

However, the composition of the infiltrates did not directly affect the incidence of atypical neurological deficits, since severe atypical deficits developed in both IFN $\gamma \mathrm{R}^{\mathrm{CNS}} \mathrm{KO}$ and IFN $\gamma \mathrm{RKO}$ chimeras, though the makeup of CNS infiltrating cells differed dramatically between these two mouse groups.

These observations suggest that the composition of the CNS-infiltrating cells is determined by IFN $\gamma$ induced events taking place both in the periphery and the CNS, but do not solely control the onset of atypical disease.
The spatial pattern of CNS infiltration is determined by IFN $\gamma$ signaling in peripheral immune cells, but does not correlate with the incidence of atypical EAE

Previous reports suggested that prominent cerebellar and/or brainstem infiltration is sufficient to initiate atypical symptoms in IFN $\gamma-/-$ mice with EAE [26,32]. To evaluate this assumption, we compared the degree of infiltration of the cerebella/brainstems of mice displaying atypical deficits with that of mice that developed typical deficits only, after EAE induction. To determine the areas of blood-brain barrier permeability, mice were injected intravenously with Evans blue (Eb) within 24 hours after the onset of neurological deficits; $90 \mathrm{~min}$ later, mice were perfused intracardially with PBS and brains and spinal cords were analyzed as described in the methods. All chimeric mice exhibited Eb staining in similar areas of the CNS (Figure 3 and Additional file 2 ). However, the depth of parenchymal $\mathrm{Eb}$ infiltration varied substantially between the groups. The CNS of mice with global absence of IFN $\gamma$ signaling (IFN $\gamma-/$ - and IFN $\gamma R K O$ chimeras) showed intense $\mathrm{Eb}$ intra- 


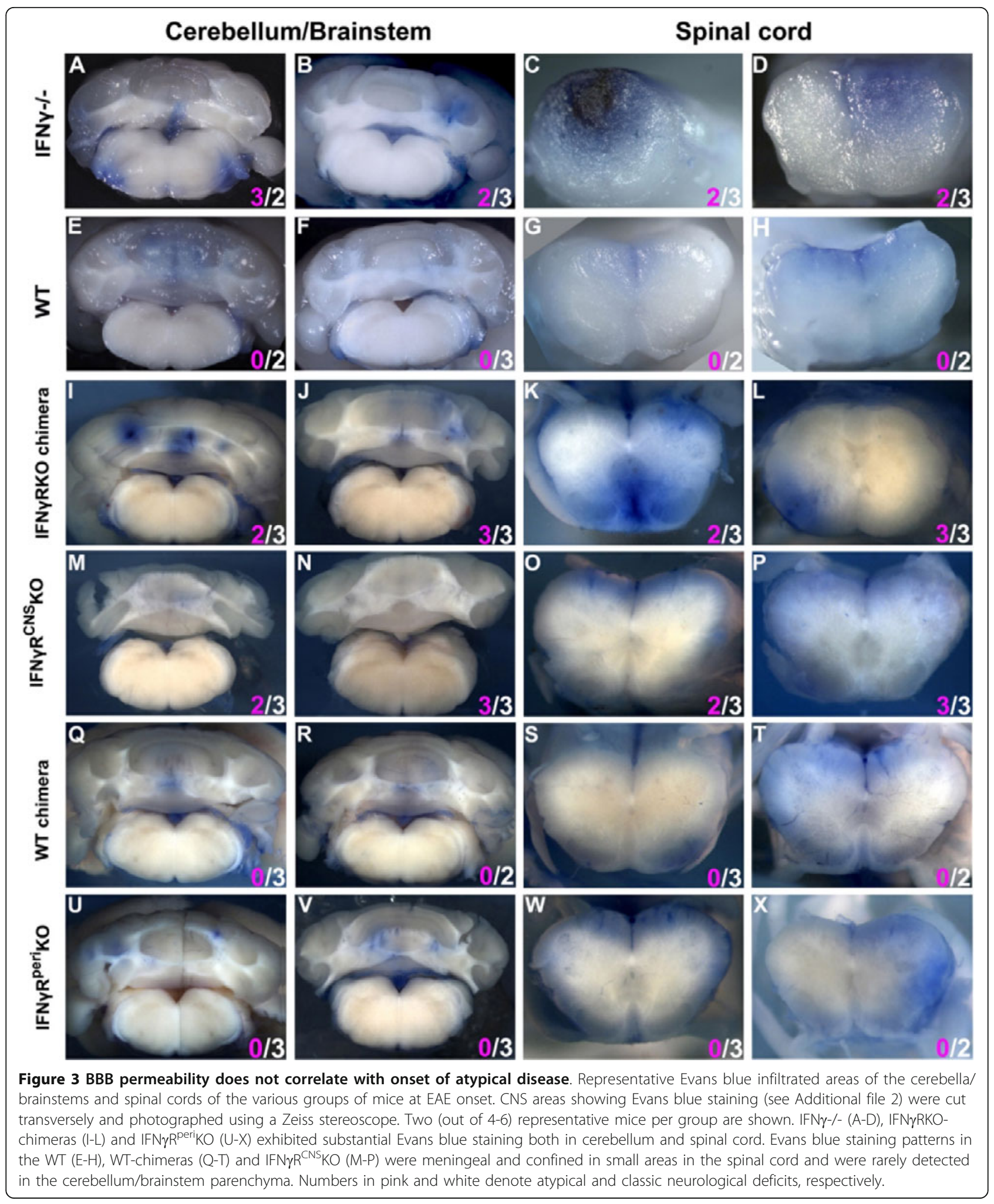


parenchymal staining, sometimes reaching the gray matter (Figure $3 \mathrm{~A}-\mathrm{D}$ and 3I-L) both in the cerebellum/ brainstem and spinal cord. Similar Eb staining patterns were observed in the CNS of IFN $\gamma \mathrm{R}^{\text {peri }} \mathrm{KO}$ mice (Figure $3 \mathrm{U}-\mathrm{X})$, extending deeply and broadly into the parenchyma. Notably, IFN $\gamma R^{\text {peri }} \mathrm{KO}$ mice showed intense Eb staining in the cerebellum and brainstem.

On the contrary, Eb+ foci in the CNS of WT mice, WT-chimeras and IFN $\gamma \mathrm{R}^{\mathrm{CNS}} \mathrm{KO}$ mice were usually confined to the meninges or minimally penetrating the glia limitans into the superficial parenchyma (Figure 3E-H and $3 \mathrm{M}-\mathrm{T})$. Furthermore, Eb staining in the parenchyma of the cerebellum/brainstem of IFN $\gamma \mathrm{R}^{\mathrm{CNS}} \mathrm{KO}$ mice was rarely observed.

As noted above, IFN $\gamma \mathrm{R}^{\mathrm{CNS}} \mathrm{KO}$ mice displayed more frequent and more severe atypical deficits than IFN $\gamma \mathrm{R}^{\text {per- }}$ ${ }^{\mathrm{i}} \mathrm{KO}$ mice. Thus the intense Eb staining in the cerebella/ brainstem of IFN $\gamma R^{\text {peri }} \mathrm{KO}$ mice compared to IFN $\gamma \mathrm{R}^{\mathrm{CNS}} \mathrm{KO}$ mice indicates that extensive infiltration of these areas is not sufficient to elicit atypical EAE.

\section{Composition of inflammatory foci within the CNS does not affect the onset of atypical neurological deficits}

Next, we tested the hypothesis that differential expression of IFN $\gamma \mathrm{R}$ causes preferential accumulation of distinct immune cell subsets in specific CNS areas (e.g. cerebellum versus spinal cord). We, thus, isolated cerebellar/brainstem, and spinal cord tissue from mice with EAE and examined the composition of their inflammatory foci by immunohistochemistry.

We used CD11b as a generic marker of inflammatory foci. CD11b is easily detectable by immunohistochemistry on infiltrating macrophages, dendritic cells and neurtophils along with NK and some CD8+ T cells [36-40]. Microglia strongly express CD11b when activated but do so only faintly when in resting state. We also used the CD45 allelic markers CD45.1 and CD45.2 to discriminate between infiltrating cells and microglia in the chimeric mice. Infiltrating CD11b+CD $45.1+$ cells in IFN $\gamma \mathrm{R}^{\mathrm{CNS}} \mathrm{KO}$ mice and WT-chimeras cells remained clustered and close to the vasculature and meninges (Figure $4 \mathrm{~A}-\mathrm{D}$ and Additional file 3). In the CNS of IFN $\gamma \mathrm{R}^{\text {peri }} \mathrm{KO}$ mice and IFN $\gamma \mathrm{RKO}$ chimeras, infiltrating $\mathrm{CD} 11 \mathrm{~b}+\mathrm{CD} 45.2+$ cells were abundant and widely distributed throughout the CNS parenchyma (Figure $4 \mathrm{E}-\mathrm{H}$ and Additional file 3). Neutrophils (Ly6G+) were abundant in the CNS of all chimeric groups on day 14 (not shown). On day 21, however, neutrophils were rarely detected in the CNS of IFN $\gamma \mathrm{R}^{\mathrm{CNS}} \mathrm{KO}$ mice (Figure 4 I-L) or WT mice and WT-chimeras (Additional file 4), but remained prominent in the CNS lesions of IFN $\gamma \mathrm{R}^{\text {peri }} \mathrm{KO}$ mice (Figure $4 \mathrm{M}-\mathrm{P}$ ) and of IFN $\gamma-/$ - mice and IFN $\gamma$ RKO-chimeras (Additional file 4). Furthermore, CD4+ T cells were more often found in perivascular and meningeal spaces and close to the glial limitans, and had only barely penetrated into the parenchyma in the CNS of IFN $\gamma \mathrm{R}^{\mathrm{CNS}} \mathrm{KO}$ (Figure $4 \mathrm{Q}-\mathrm{T}$ ) WT mice and WT-chimeras (Additional file 5). On the contrary, CD4 $+\mathrm{T}$ cells were usually found deep in the parenchyma in the CNS of IFN $\gamma \mathrm{R}^{\text {peri }} \mathrm{KO}$ (Figure $4 \mathrm{U}-\mathrm{X}$ ), IFN $\gamma-/$ - and IFN $\gamma$ RKO chimeras (Additional file 5),

Anti-IBA1 antibody labels more intensely activated and quiescent microglia, and less intensely, infiltrating macrophages. IBA $1+$ cells migrated to the site of infiltration and were in close contact with neutrophils and CD4+ T cells (Figure 4), probably attempting to control tissue damage. By staining for the CD45 allele markers CD45.1/CD45.2, we verified that the cells interacting with infiltrating CD4+T and Ly6G+ cells are of recipient origin (i.e: microglia, Additional file 6).

In summary and in agreement with the Eb patterns, these data show that infiltrates in IFN $\gamma$-/-, IFN $\gamma$ RKOchimeras and IFN $\gamma \mathrm{R}^{\text {peri }} \mathrm{KO}$ mice penetrated deeply into the parenchyma and were widely scattered, whereas inflammatory foci in WT mice, WT-chimeras and IFN $\gamma \mathrm{R}^{\mathrm{CNS}} \mathrm{KO}$ mice were constrained to the perivascular spaces and the meninges and tightly clustered together. Lesion composition was similar in all mice, consisting of CD4+T, CD11b+ and IBA1+ cells. The main difference in the inflammatory foci between the groups of mice was the persistence of Ly6G+ neutrophils in IFN $\gamma-$ /IFN $\gamma$ RKO chimeras and IFN $\gamma R^{\text {peri }} \mathrm{KO}$ a week after disease onset (day 21), at which time point they were sparsely observed in WT mice, WT-chimeras and IFN $\gamma \mathrm{R}^{\mathrm{CNS}} \mathrm{KO}$ mice. These data, in agreement with our flow cytometry results, indicate that the intra-lesion composition is not directly associated with the onset of atypical EAE. However, intense intercellular interactions between microglia and infiltrating cells may play deciding roles on the actions of peripheral cells after these enter the CNS parenchyma.

\section{The patterns of axonal degeneration are not linked to the} development of atypical symptoms

Cumulative axonal injury is largely responsible for the development of permanent neurological disability in MS patients and animals with EAE $[1,2,41,42]$. We speculated that in the absence of IFN $\gamma$ signaling in the CNS, axonal damage would be more severe, in the cerebellum and brainstem (areas that control posture), or in areas of the spinal cord, as unilateral damage of the spinal cord has been associated with balance impairments, such as leaning towards one side and disequilibrium [43]. To detect axonal damage by immunohistochemistry, we used the SMI32 antibody, which is specific for hypophosphorylated neurofilament $\mathrm{H}$ (hypo-NF-H). Hypo-NF-H resides only in neuronal bodies of the gray matter of the healthy spinal cord. In the healthy CNS, 


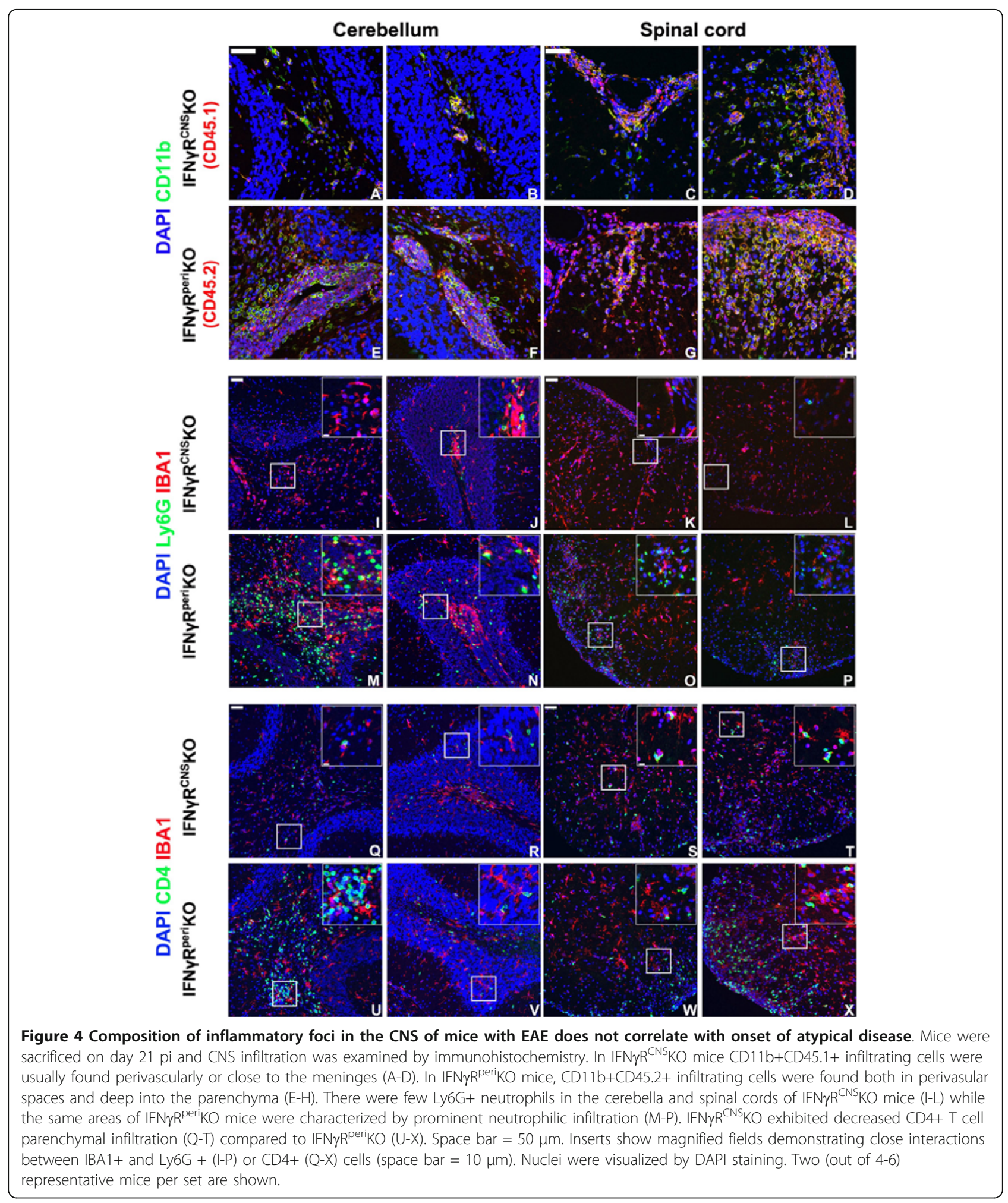




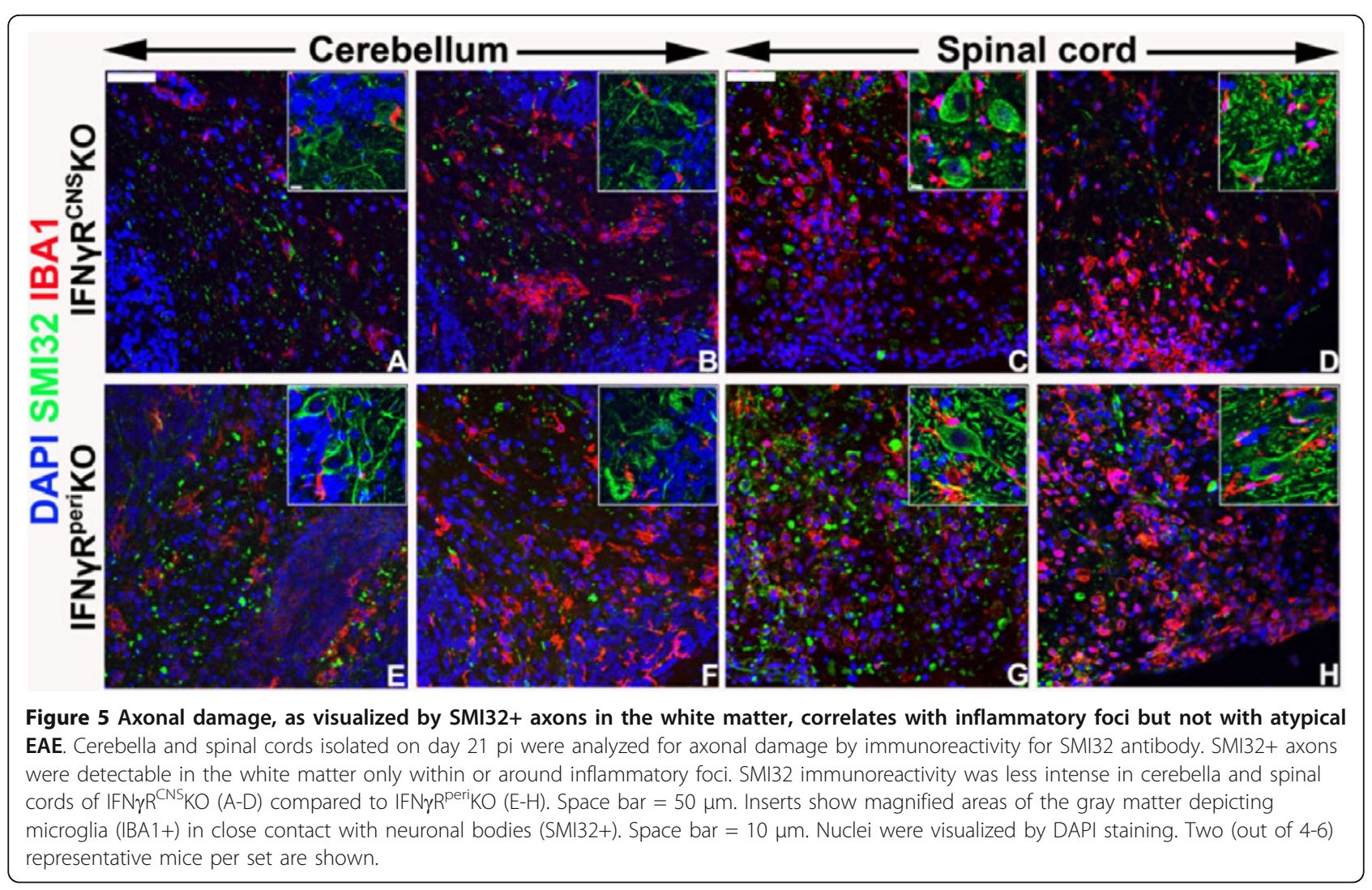

SMI32 immunoreactivity is not detected in the white matter (Additional file 7). SMI32 immunoreactivity, within the white matter is indicative of accumulation of hypo-NF-H in axons, reflecting axonal flow disturbances, degeneration or transection $[1,44]$.

The pattern of SMI32 immunoreactivity in the white matter correlated with the degree of infiltration. Axonal damage occurred only within and around inflammatory foci. Thus, IFN $\gamma$-/- mice, IFN $\gamma \mathrm{RKO}$-chimeras and IFN $\gamma R^{\text {peri }} \mathrm{KO}$ mice showed intense SMI32 immunoreactivity both in the cerebellum and spinal cord compared to WT mice, WT-chimeras IFN $\gamma \mathrm{R}^{\mathrm{CNS}} \mathrm{KO}$ mice (Figure 5, Additional file 7). However, quantification of SMI32 immunoreactive axons within the white matter of chimeric mice with EAE did not show statistically significant differences between the groups (Additional file 7).

Quantification of demyelinating foci in the same sections visualized by absence of myelin basic protein (MBP) showed no difference between the groups in the spinal cord. Interestingly, however, the cerebellum of IFN $\gamma \mathrm{R}^{\mathrm{CNS}} \mathrm{KO}$ mice with EAE exhibited smaller and fewer areas of demyelinating foci (Additional File 8), although this did not reach statistical significance $(\mathrm{p}=$ 0.0522).

These data indicate that the pattern of axonal damage as detected by accumulation of hypo-NF-H in the white matter could not account for the onset of atypical neurological deficits. However, in the CNS of all bone marrow chimeric mice with EAE, IBA1+ microglia were found in close contact with neuronal perikarya and axons (Figure 5 and Additional file 7), suggesting that these intercellular communications affect neuronal function.

Atypical neurological deficits develop preferentially in the absence of microglial IFN $\gamma$ R-STAT1 signaling

STAT1 is upregulated in the CNS only in response to IFN $\gamma$ In the absence of reliable antibodies against IFN $\gamma \mathrm{R}$ for immunohistochemistry, to identify the cell type(s) that respond to IFN $\gamma$ signaling we examined the expression patterns of the transcription factor STAT1 that is downstream from IFN $\gamma$ R. STAT1 was not detected in the healthy CNS (Additional file 9). To confirm that STAT1 is upregulated only in cells that express IFN $\gamma \mathrm{R}$, we initially examined STAT1 expression by co-labeling for CD45.1 or CD45.2. In IFN $\gamma$ RKO-chimeras, both microglia and infiltrating cells carried the CD45.2 allele. STAT1 was rarely detected and only within inflammatory foci (Figure $6 \mathrm{~A}-\mathrm{D})$ ). On the contrary, WT-chimeras with EAE showed abundant STAT1 expression in both infiltrating (CD45.1+) and resident cells (CD45.1-) (Figure $6 \mathrm{I}-\mathrm{L})$. In the $\mathrm{CNS}$ of IFN $\gamma \mathrm{R}^{\mathrm{CNS}} \mathrm{KO}$ mice with EAE, 


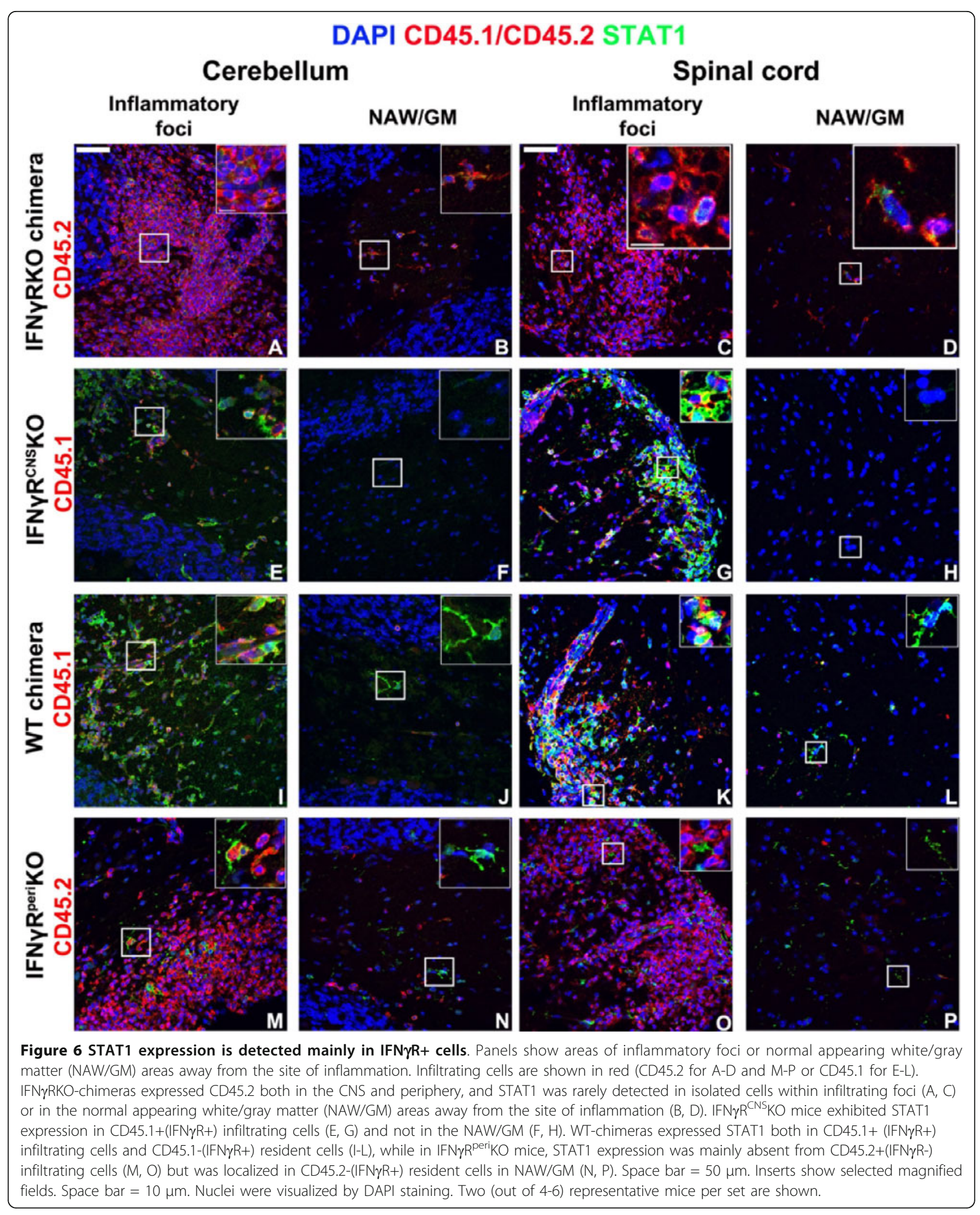


infiltrating CD45.1+ (IFN $\gamma \mathrm{R}+)$, but not resident CD45.1(IFN $\gamma \mathrm{R}$-) cells, expressed STAT1 (Figure $6 \mathrm{E}-\mathrm{H}$ ). In IFN $\gamma \mathrm{R}^{\text {peri }} \mathrm{KO}$ mice, STAT1 was expressed by resident CD45.2- (IFN $\gamma \mathrm{R}+$ ) but not infiltrating CD45.2+ (IFN $\gamma \mathrm{R}-$ ) cells (Figure $6 \mathrm{M}-\mathrm{P}$ ). These observations indicated that in the inflamed CNS, STAT1 is specifically upregulated in response to IFN $\gamma$ signaling.

\section{IFN $\gamma$ signals mainly in CD11b+ cells in the inflamed CNS}

Further examination revealed that STAT1 was upregulated mainly in CD11b + cells with intact IFN $\gamma$ signaling (Figure 7). STAT1 was almost absent in the CNS parenchyma of IFN $\gamma-/$ - and IFN $\gamma$ RKO chimeras with EAE, although CD11b immunoreactivity was abundant (Figure 7 A-D and 7I-L). In WT mice and WT-chimeras with EAE, STAT1 immunoreactivity was abundant in CD11b + cells in inflammatory foci representing infiltrating cells and activated microglia, both in the cerebellum and the spinal cord (Figure 7 E, G and 7Q, S). Furthermore $\mathrm{CD} 11 \mathrm{~b}+$ cells with ramified morphology further from the site of inflammation in the otherwise normal appearing white and gray matter were also STAT1 positive (Figure 7 F, H and 7R, T). This suggests that microglia respond to IFN $\gamma$ signaling even when they are not in close contact with infiltrating cells. In IFN $\gamma \mathrm{R}^{\mathrm{CNS}} \mathrm{KO}$ mice, STAT1 was upregulated in CD11b+ cells within the inflammatory foci (IFN $\gamma \mathrm{R}+$ ) but not in $\mathrm{CD} 11 \mathrm{~b}+$ resident cells (IFN $\gamma \mathrm{R}$-) (Figure $7 \mathrm{M}-\mathrm{P}$ ). In IFN $\gamma \mathrm{R}^{\text {peri }} \mathrm{KO}$ mice, STAT1 expression was prevalent in CD11b+ cells with microglial morphology (resident cells, IFN $\gamma \mathrm{R}+$ ) and not in infiltrating cells (IFN $\gamma \mathrm{R}-$ ) in the white matter (Figure $7 \mathrm{U}-\mathrm{X})$. Occasionally, STAT1 expression was detected in GFAP+ cells (astrocytes) found close to inflammatory foci, but only in the presence of intact IFN $\gamma$ signaling within the CNS (Additional file 10). Furthermore, STAT1 was usually found within the nucleus, suggesting activation of the STAT1 trancription process (Additional File 11).

These data clearly show that, IFN $\gamma$-elicited STAT1 responses in the inflamed CNS are largely restricted to CD11b+ cells. Absence of STAT1 in infiltrating CD11b+ cells does not correlate to a large extent with the onset of atypical EAE (IFN $\gamma \mathrm{R}^{\text {peri }} \mathrm{KO}$ mice). On the contrary, atypical neurological deficits are strongly associated with inactivation of the IFN $\gamma$-STAT1 signaling pathway in microglia (IFN $\gamma \mathrm{R}^{\mathrm{CNS}} \mathrm{KO}$ mice).

\section{Discussion}

In the past, the development of atypical EAE in mice without IFN $\gamma$ signaling has been attributed to preferential infiltration of the cerebellum and/or brainstem by activated immune cells, increased generation of Th17 cells in the periphery, and/or formation of neutrophilrich posterior fossa inflammatory foci [24,45-47]. To a large extent, these conclusions were derived from studies of adoptively transferred EAE, a paradigm that does not allow for clear discrimination of immune cells derived from the donor and host. Therefore, to discriminate between the actions of IFN $\gamma$ in the CNS and the periphery, we constructed irradiation bone marrow chimeric mice lacking IFN $\gamma \mathrm{R}$ in CNS cells but not peripheral immune cells or vice versa. After EAE induction, mice without IFN $\gamma \mathrm{R}$ in radioresistant CNS cells (IFN $\gamma \mathrm{R}^{\mathrm{CNS}} \mathrm{KO}$ ) had more severe and more frequent atypical neurological deficits as compared to mice lacking IFN $\gamma \mathrm{R}$ in radiosensitive peripheral immune cells (IFN $\gamma \mathrm{R}$ $\left.{ }^{\text {peri }} \mathrm{KO}\right)$. Histological and flow cytometry analysis showed that lesion distribution, inflammatory cell populations within the CNS and intra-lesion composition of the inflammatory foci did not correlate with the incidence of atypical EAE. In contrast to what we had anticipated, cerebellar/brainstem areas of IFN $\gamma \mathrm{R}^{\mathrm{CNS}} \mathrm{KO}$ mice exhibited low levels of infiltration while the same areas of IFN $\gamma \mathrm{R}^{\text {peri }} \mathrm{KO}$ mice were heavily populated by peripheral immune cells. Furthermore, the numbers of Th17 cells and neutrophils in the CNS did not correlate with the presence or absence of atypical EAE. In conjunction with the previous studies mentioned above, our observations indicate that although cerebellar/brainstem infiltrates of neutrophils and Th17 cells may be necessary to cause atypical EAE, they are not sufficient alone to do so. This led us to the conclusion that the CNS resident cell responses in the absence of IFN $\gamma$ signaling may be responsible for the onset of atypical EAE.

We used STAT1 as a surrogate marker to identify cell targets of IFN $\gamma$ signaling. STAT1 was detected mainly on CD11b+ cells, both in the inflammatory foci and in normal appearing white and gray matter. Although we can not exclude STAT1-independent events, these data show that IFN $\gamma$ actions in the CNS are exerted in microglia and infiltrating CD11b+cells. Furthermore, IFN $\gamma \mathrm{R}^{\mathrm{CNS}} \mathrm{KO}$ mice with severe atypical EAE showed virtually no STAT1 expression in microglia, but STAT1 upregulation was detected in infiltrating CD11b+ cells. On the contrary, STAT1 was not detected in infiltrating CD11b+ cells, but was widely expressed in microglia in IFN $\gamma \mathrm{R}^{\text {peri }} \mathrm{KO}$ mice, which showed mild or no atypical deficits. These data suggest that deletion of IFN $\gamma$ signaling in microglia, but not in infiltrating CD11b+ cells, correlates with atypical EAE. This conclusion is further strengthened by the prior observation that mice without STAT1 suffer a fulminant form of EAE [46].

Microglia (IBA1+ cells that were of host origin as verified by immunohistochemistry for the appropriate CD45 allele) were closely apposed to infiltrating CD4+ and Ly6G+ cells in the CNS of EAE mice, and thus may have modulated the properties of these peripheral immune cells after their entry into the CNS $[48,49]$. 


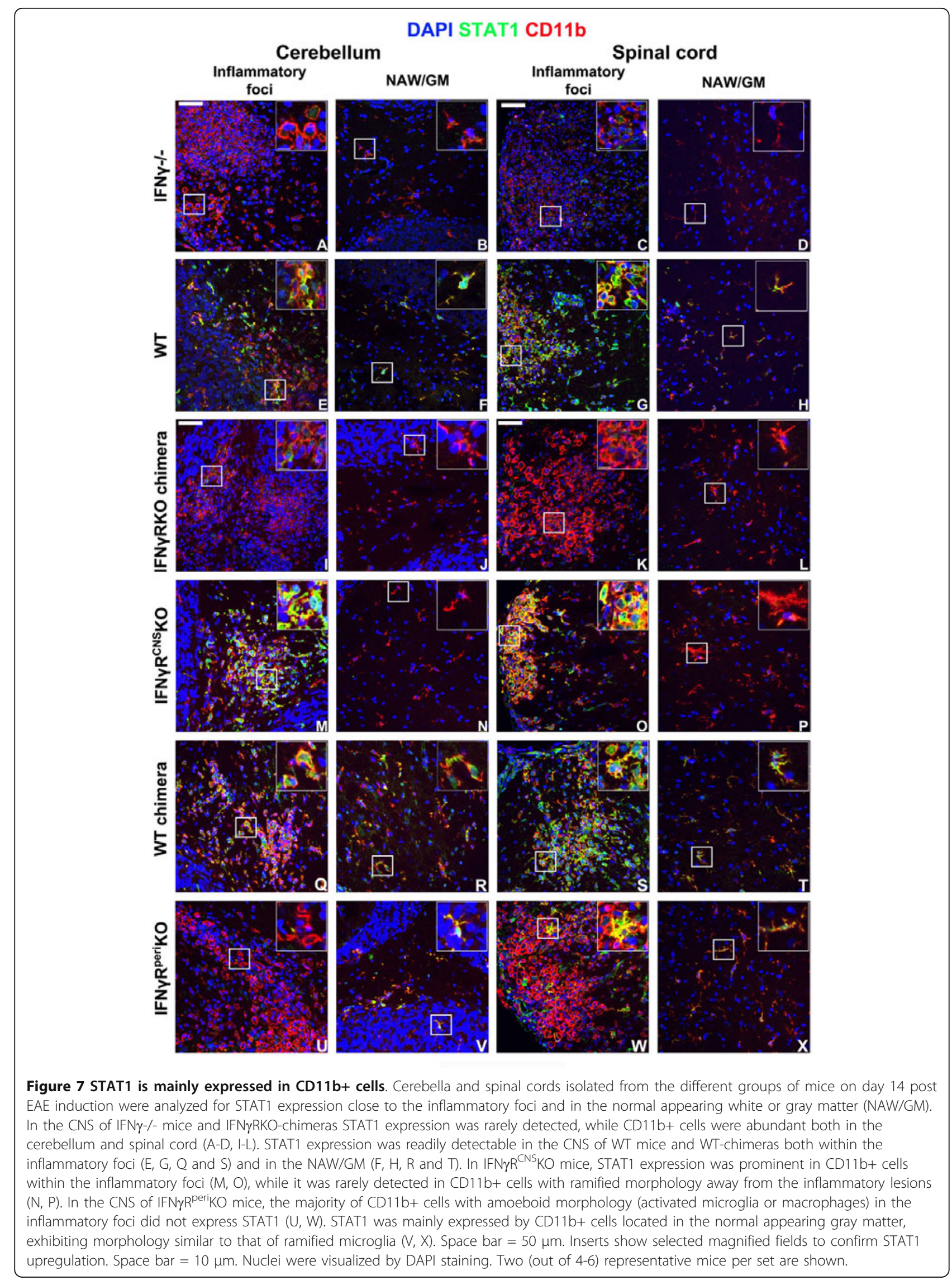


Activated microglia were also in close contact with neuronal perikarya and axons in the EAE mice. Upon activation, microglia may either promote neurogenesis, and support neuronal function [50-52], or accelerate or induce damage [53-55]. It is likely that in the absence of IFN $\gamma$ signaling microglia become neurotoxic causing damage in spinocerebellar, cerebrospinal and propriospinal tracts that control balance and posture; these tracts transverse both the brain stem and the spinal cord. Damaged axons are most abundant in and around inflammatory foci in EAE, and are likely to contribute to motor deficits such as ascending paralysis [1]. However, the extent of axonal damage as detected by SMI32 immunoreactivity in the cerebellum and spinal cord was not correlated with the incidence of atypical EAE, though it is possible that axonal and neuronal damage detectable by techniques other than SMI32 immunostaining (e.g., alterations in mitochondrial morphology [56], dysregulated $\mathrm{Na}+$ channel expression [57], or disruption of neuronal microtubule network [44]) may prove to be associated with atypical neurological deficits.

Our data suggest that, in the inflamed CNS, IFN $\gamma \mathrm{R}$ STAT1 signaling is one of the factors that determines whether microglia acquire a neuroprotective or neurotoxic properties. Though the extent of neuronal death was minimal and not different in the cerebella and spinal cords of the various chimeric mice as assessed by TUNEL (data not shown) we suspect that IFN $\gamma \mathrm{R}$ deficient microglial responses induce physiological alterations in the properties of specific subsets of cerebellar/ brainstem neurons that lead to circling [58] and other atypical neurological symptoms.

\section{Conclusions}

In the present study, we demonstrated that in EAE the development of deficits associated with vestibular dysfunction is not dependent solely on cerebellar and brainstem infiltration by peripheral immune cells, or the composition and localization of inflammatory foci within the CNS. Our data support the hypothesis that inhibition of IFN $\gamma$ actions mediated through microglial STAT1 is the main direct (cross-talk with neurons) or indirect (cross-talk with infiltrating cells, or astrocytes) cause for the onset of atypical neurological deficits. Modulation of IFN $\gamma$-STAT1 responses in microglia might prove a promising therapy for cerebellar/vestibular dysfunction in neuroinflammatory disorders.

\section{Additional material}

Additional file 1: Table 1: Immune cell subsets in periphery (MOGrecall) and the CNS of IFN $\gamma$-/- and WT mice with EAE. P values were calculated using Mann-Whitney $\mathrm{U}$ test with Bonferroni correction. Six to nine mice were analyzed per time point in each group. Table 2:
Immune cell subsets in periphery and the CNS of the chimeric mouse groups with EAE. P values were calculated using Kruskal-Wallis test with post-hoc Mann-Whitney $U$ tests with Bonferroni correction. Six mice were analyzed per group in each time point.

Additional file 2: Macroscopic photographs showing BBB permeability. Macroscopic photographs of spinal cords and brains isolated up to 24 hrs post the onset of neurological deficits and 90 minutes after Evans blue intravenous administration. Tissues were photographed using the Zeiss SteREO Lumar.V12 stereoscope and tiled together using Photoshop.

Additional file 3: CD11b+ cells distribution in the inflamed CNS. CD11b+ cells were abundant in the cerebella and spinal cords of IFNyRKO-chimeras and WT chimeras on day 21 pi. CD11b+CD45.2+ cells were found within the CNS parenchyma of IFN $\gamma$ RKO-chimeric mice (both infiltrating and resident microglia express CD45.2 in this chimeric group, A-D). In the CNS of WT-chimeras, infiltrating CD45.1+CD11b+ cells (E-H) were usually found perivascularly or close to the meninges. Nuclei were visualized by DAPI staining. Two (out of 4-6) representative mice per set are shown. Space bar $=50 \mu \mathrm{m}$.

Additional file 4: Neutrophil distribution in the inflamed CNS. On day $21 \mathrm{pi}$, cerebella and spinal cords of IFN $\gamma$-/- mice were heavily populated by Ly6G+ neutrophils (A-D), while the same areas of WT mice exhibited low level and spatially confined neutrophilic infiltration (E- H). Ly6G+ neutrophils were abundant in the cerebella and spinal cords of IFNyRKO-chimeras (I-L) but only sparsely detected in WT-chimeras (M-P). Nuclei were visualized by DAPI staining. Space bar $=50 \mu \mathrm{m}$. Inserts show magnified fields demonstrating close interactions between $\mid B A 1+$ and Ly6G+ cells (space bar $=10 \mu \mathrm{m}$ ). Two (out of 4-6) representative mice per set are shown.

Additional file 5: CD11b+ cells distribution in the inflamed CNS. Cerebella and spinal cords of IFN $\gamma-/-(A-D)$ and IFNyRKO-chimeras (I-L) exhibited increased parenchymal infiltration by $\mathrm{CD} 4+\mathrm{T}$ cells compared to WT (E-H), and WT-chimeras (M-P), respectively. Two (out of 4-6) representative mice per set are shown. Nuclei were visualized by DAPI staining. Space bar $=50 \mu \mathrm{m}$. Inserts show magnified fields demonstrating close interactions between IBA1+ and CD4+ cells (space bar $=10 \mu \mathrm{m})$.

Additional file 6: Resident microglia interact with infiltrating cells. Resident microglia cells identified by CD45.2 (pseudo green) for IFNyR ${ }^{\mathrm{CNS}} K O(A, B, G, H)$ and WT-chimeras $(C, D, I, J)$ or CD45.1 (pseudo green) IFNyR ${ }^{\text {peri } K O}(E, F, K, L)$ closely interact with CD4+ (A-F) and Ly6G+ (G-L) infiltrating cells (pseudo red). Two (out of 4-6) representative mice per set are shown. Nuclei were visualized by DAPI staining. Space bar $=$ $50 \mu \mathrm{m}$.

Additional file 7: Axonal damage as visualized by SMI32+ axons in the white matter does not correlate with atypical EAE. Spinal cords and cerebella isolated from healthy mice and EAE mice on day $21 \mathrm{pi}$ were analyzed for axonal damage by immunoreactivity for

hypophosphorylated neurofilament- $\mathrm{H}$ in the white matter, using the SMI32 antibody. SMI32+ axons were not detected in the healthy white matter (A-D). SMI32 immunoreactivity is readily detected in healthy neuronal bodies within the gray matter (inserts in panels A-D). SMI32+ axons were detectable in the white matter only within or around the inflammatory foci and were more intense in the cerebella and spinal cords of IFN $\gamma$-/- mice (E-H), and IFN $\gamma$ RKO-chimeras (M-P) compared to WT mice $(I-L)$, and WT-chimeras $(\mathrm{Q}-\mathrm{T})$. IBA $1+$ cells were found in close proximity to SMI32+ axons in the white matter in all groups of mice. Nuclei were visualized by DAPI staining. Two (out of 4-6) representative mice per set are shown. Space bar $=50 \mu \mathrm{m}$. Inserts show magnified areas of the gray matter depicting IBA1+ cells in contact with neuronal bodies. Space bar $=10 \mu \mathrm{m}$. Panel $U$ shows the quantification of SMI32+ axons per $\mathrm{mm}^{2}$ of white matter of spinal cords or cerebella isolated from the chimeric mouse groups with EAE on day 21.

Additional file 8: Loss of myelin does not correlate with the onset of atypical neurological dificits. Fields encompassing the whole spinal cord or cerebellum, isolated from chimeric groups with EAE on day 21 and stained with anti-MBP antibody, were photographed using a 20X objective mounted on a Nikon laser scanning confocal microscope, and 
images were tiled together using the Nikon NIS-Elements. MBP negative areas were traced and quantified using the ImageJ software. Panels A-H show representative cerebellar and spinal cord sections stained with MBP; areas of demyelination are traced in white and white matter is traced in green. Panel I shows the quantification of MBP-negative areas as $\mathrm{mm}^{2} / \mathrm{mm}^{2}$ of white matter. On day 14 , IFN $\gamma \mathrm{R}^{\mathrm{CNS}} \mathrm{KO}$ mice showed fewer and smaller demyelinating foci compare to the other groups and this difference approached statistical significance $(p=0.0522)$. No other statistically significant difference was observed between the groups.

Additional file 9: STAT1 was not detected in healthy CNS of nonirradiated (A-D) or chimeric (E-H) mice. CD11b immunoreactivity was not detected in healthy CNS, since microglia are not activated. Nuclei were visualized by DAPI staining. Space bar $=50 \mu \mathrm{m}$.

Additional file 10: STAT1 is expressed only in few GFAP+ astrocytes usually close to inflammatory foci. STAT1 was not detected in GFAP+ astrocytes in IFNy-/- (A-D) or IFNyRKO chimeras (I-L). In the CNS of IFNyR ${ }^{\mathrm{CNS}} \mathrm{KO}(\mathrm{M}-\mathrm{P})$ and IFN $\gamma \mathrm{R}^{\text {peri }} \mathrm{KO}(\mathrm{U}-\mathrm{X})$, GFAP+ cells rarely expressed STAT1, but were routinely found in close contact with STAT1 expressing cells. STAT1 was occasionally detected in astrocytes close to a lesion in the CNS of WT mice (E-H) and WT-chimeras (Q-T). Nuclei were visualized by DAPI staining. Two (out of 4-6) representative mice per set are shown. Space bar $=50 \mu \mathrm{m}$. Inserts show magnified fields. Space bar $=10 \mu \mathrm{m}$.

\section{Additional file 11: STAT1 translocates to the nucleus. Sections}

isolated from the cerebellum and spinal cord of chimeric mice with EAE were stained with anti-STAT1 (green) and anti-CD11b (red). The sections were imaged using a $60 \times$ objective mounted on a Nikon laser scanning confocal microscope. Panels A, B, C and D are stacked images of 14 sequential planes each $0.7 \mu \mathrm{m}$ thick. Panels $\mathrm{A}^{\prime} \mathrm{B}^{\prime} \mathrm{C}^{\prime}$ and $\mathrm{D}^{\prime}$ are single plane orthogonal confocal images showing STAT1 translocation into the nucleus. Nuclei were visualized by DAPI staining. Space bar $=50 \mu \mathrm{m}$.

\section{Abbreviations}

BMC: bone marrow chimera; CNS: central nervous system; EAE: experimental autoimmune encephalomyelitis; Eb: Evans blue; Hypo-NF-H:

hypophosporylated neurofilament heavy; IFNY: interferon-gamma; IFNYR: IFNy receptor; pi: post immunization; KO: knockout; NK: natural killer cells; STAT1: signal transducer and activator of transcription 1; Th: T helper cells; Tregs: regulatory CD4+ T cells; WT: wild type

\section{Acknowledgements}

This work was supported by Shriners Hospitals for Children, National Institutes of Health [RO1 NS025044] and National Multiple Sclerosis Society [RG 4397-A-5]

The authors are grateful to Paul Ashwood, Andrew E. Gelman, Peter Bannerman, and lannis E. Adamopoulos for reading the manuscript and providing critical suggestions.

\section{Author details}

'Institute for Pediatric Regenerative Medicine, Shriners Hospitals for Children Northern California, Sacramento, California, USA, 95817. ²Department of Dermatology, School of Medicine, University of California, Davis Sacramento, California, USA, 95816. ${ }^{3}$ The Department of Neurology, School of Medicine, University of California Davis, Sacramento, California, USA, 95817.

\section{Authors' contributions}

EL performed all the experiments, analyzed data, prepared figures and help in the writing of the manuscript, SC assisted EL in collecting flow cytometry and immunohistochemistry data, DP provided help with the interpretation of axonal degeneration data, read and thoroughly reviewed the manuscript, AMS was responsible and oversaw the whole study, analyzed data and wrote the manuscript.

All authors have read and approved the final manuscript.

\section{Competing interests}

The authors declare that they have no competing interests.
Received: 16 July 2011 Accepted: 16 January 2012

Published: 16 January 2012

\section{References}

1. Soulika AM, Lee E, McCauley E, Miers L, Bannerman P, Pleasure D: Initiation and Progression of Axonopathy in Experimental Autoimmune Encephalomyelitis. Journal of Neuroscience 2009, 29:14965-14979.

2. Trapp BD, Stys PK: Virtual hypoxia and chronic necrosis of demyelinated axons in multiple sclerosis. Lancet Neurol 2009, 8:280-291.

3. Langdon DW, Thompson AJ: Multiple sclerosis: a preliminary study of selected variables affecting rehabilitation outcome. Multiple Sclerosis 1999, 5:94-100.

4. Naismith RT, Trinkaus $\mathrm{K}$, Cross AH: Phenotype and prognosis in AfricanAmericans with multiple sclerosis: a retrospective chart review. Multiple Sclerosis 2006, 12:775-781.

5. Zaaraoui W, Reuter F, Rico A, Faivre A, Crespy L, Malikova I, Soulier E, Viout $P$, Le Fur $Y$, Confort-Gouny $S$, et al: Occurrence of neuronal dysfunction during the first 5 years of multiple sclerosis is associated with cognitive deterioration. Journal of Neurology 2010.

6. Boehm U, Klamp T, Groot M, Howard JC: Cellular responses to interferongamma. Annual Review of Immunology 1997, 15:749-795.

7. Farrar MA, Schreiber RD: The Molecular Cell Biology of Interferon-Gamma and Its Receptor. Annual Review of Immunology 1993, 11:571-611.

8. Neumann $H$, Schmidt $H$, Wilharm E, Behrens L, Wekerle H: Interferon gamma gene expression in sensory neurons: Evidence for autocrine gene regulation. Journal of Experimental Medicine 1997, 186:2023-2031.

9. Sun L, Tian ZZ, Wang JP: A direct cross-talk between interferon-gamma and sonic hedgehog signaling that leads to the proliferation of neuronal precursor cells. Brain Behavior and Immunity 2010, 24:220-228.

10. Kelchtermans $H$, Billiau $A$, Matthys $P$ : How interferon-gamma keeps autoimmune diseases in check. Trends Immunol 2008, 29:479-486.

11. Muhl H, Pfeilschifter J: Anti-inflammatory properties of pro-inflammatory interferon-gamma. Int Immunopharmacol 2003, 3:1247-1255.

12. Chu CQ, Wittmer S, Dalton DK: Failure to suppress the expansion of the activated CD4 T cell population in interferon gamma-deficient mice leads to exacerbation of experimental autoimmune encephalomyelitis. Journal of Experimental Medicine 2000, 192:123-128.

13. Dalton DK, Haynes L, Chu CQ, Swain SL, Wittmer S: Interferon gamma eliminates responding CD4 T cells during mycobacterial infection by inducing apoptosis of activated CD4 T cells. Journal of Experimental Medicine 2000, 192:117-122.

14. Wang ZJ, Hong J, Sun W, Xu GW, Li NL, Chen X, Liu A, Xu LY, Sun B, Zhang JWZ: Role of IFN-gamma in induction of Foxp3 and conversion of CD4(+)CD25(-) T cells to CD4(+) Tregs. Journal of Clinical Investigation 2006, 116:2434-2441.

15. Hashioka S, Klegeris A, Schwab C, McGeer PL: Interferon-gammadependent cytotoxic activation of human astrocytes and astrocytoma cells. Neurobiology of Aging 2009, 30:1924-1935.

16. Popko B, Corbin JG, Baerwald KD, Dupree J, Garcia AM: The effects of interferon-gamma on the central nervous system. Molecular Neurobiology 1997, 14:19-35.

17. Rubio N, Defelipe C: Demonstration of the Presence of a Specific Interferon-Gamma Receptor on Murine Astrocyte Cell-Surface. Journal of Neuroimmunology 1991, 35:111-117.

18. Torres C, Aranguez I, Rubio N: Expression of Interferon-Gamma Receptors on Murine Oligodendrocytes and Its Regulation by Cytokines and Mitogens. Immunology 1995, 86:250-255.

19. Tsuda M, Masuda T, Kitano J, Shimoyama H, Tozaki-Saitoh H, Inoue K: IFNgamma receptor signaling mediates spinal microglia activation driving neuropathic pain. Proceedings of the National Academy of Sciences of the United States of America 2009, 106:8032-8037.

20. Vikman K, Robertson B, Grant G, Liljeborg A, Kristensson K: Interferongamma receptors are expressed at synapses in the rat superficial dorsal horn and lateral spinal nucleus. Journal of Neurocytology 1998, 27:749-759.

21. Billiau A, Heremans $H$, Vandekerckhove F, Dijkmans R, Sobis H, Meulepas E, Carton H: Enhancement of Experimental Allergic Encephalomyelitis in Mice by Antibodies against Ifn-Gamma. Journal of Immunology 1988, 140:1506-1510.

22. Furlan $R$, Brambilla E, Ruffini F, Poliani PL, Bergami A, Marconi PC, Franciotta DM, Penna G, Comi G, Adorini L, Martino G: Intrathecal delivery of IFN-gamma protects $\mathrm{C} 57 \mathrm{BL} / 6$ mice from chronic-progressive 
experimental autoimmune encephalomyelitis by increasing apoptosis of central nervous system-infiltrating lymphocytes. Journal of Immunology 2001, 167:1821-1829.

23. Voorthuis JA, Uitdehaag BM, De Groot CJ, Goede PH, van der Meide PH, Dijkstra CD: Suppression of experimental allergic encephalomyelitis by intraventricular administration of interferon-gamma in Lewis rats. Clin Exp Immunol 1990, 81:183-188.

24. Lees JR, Golumbek PT, Sim J, Dorsey D, Russell JH: Regional CNS responses to IFN-gamma determine lesion localization patterns during EAE pathogenesis. Journal of Experimental Medicine 2008, 205:2633-2642.

25. Willenborg DO, Fordham SA, Staykova MA, Ramshaw IA, Cowden WB: IFNgamma is critical to the control of murine autoimmune encephalomyelitis and regulates both in the periphery and in the target tissue: A possible role for nitric oxide. Journal of Immunology 1999, 163:5278-5286.

26. Lees JR, Iwakura $Y$, Russell JH: Host T cells are the main producers of IL-17 within the central nervous system during initiation of experimental autoimmune encephalomyelitis of Th1 cell lines. Journal of Immunology 2008, 180:8066-8072

27. Skundric DS, Kim C, Tse HY, Raine CS: Homing of T cells to the central nervous system throughout the course of relapsing experimental autoimmune encephalomyelitis in Thy-1 congenic mice. Journal of Neuroimmunology 1993, 46:113-121.

28. Kuerten S, Kostova-Bales DA, Frenzel LP, Tigno JT, Tary-Lehmann M, Angelov DN, Lehmann PV: MP4- and MOG:35-55-induced EAE in C57BL/6 mice differentially targets brain, spinal cord and cerebellum. Journal of Neuroimmunology 2007, 189:31-40.

29. Tonra JR: Cerebellar susceptibility to experimental autoimmune encephalomyelitis in SJL/J mice: potential interaction of immunology with vascular anatomy. Cerebellum 2002, 1:57-68.

30. Zheng JZ, Bizzozero OA: Accumulation of Protein Carbonyls Within Cerebellar Astrocytes in Murine Experimental Autoimmune Encephalomyelitis. Journal of Neuroscience Research 2010, 88:3376-3385.

31. Bannerman P, Hahn A, Soulika A, Gallo V, Pleasure D: Astrogliosis in EAE spinal cord: Derivation from radial glia, and relationships to oligodendroglia. Glia 2007, 55:57-64.

32. Abromson-Leeman S, Bronson R, Luo Y, Berman M, Leeman R, Leeman J, Dorf $\mathrm{M}$ : T-cell properties determine disease site, clinical presentation, and cellular pathology of experimental autoimmune encephalomyelitis. American Journal of Pathology 2004, 165:1519-1533.

33. Tran EH, Prince EN, Owens T: IFN-gamma shapes immune invasion of the central nervous system via regulation of chemokines. Journal of Immunology 2000, 164:2759-2768.

34. Siffrin V, Radbruch H, Glumm R, Niesner R, Paterka M, Herz J, Leuenberger T, Lehmann SM, Luenstedt S, Rinnenthal JL, et al: In vivo imaging of partially reversible th17 cell-induced neuronal dysfunction in the course of encephalomyelitis. Immunity 2010, 33:424-436.

35. Pollinger B, Krishnamoorthy G, Berer K, Lassmann H, Bosl MR, Dunn R, Domingues HS, Holz A, Kurschus FC, Wekerle H: Spontaneous relapsingremitting EAE in the SJL/J mouse: MOG-reactive transgenic T cells recruit endogenous MOG-specific B cells. Journal of Experimental Medicine 2009, 206:1303-1316.

36. De la Hera A, Alvarez-Mon M, Sanchez-Madrid F, Martinez C, Durantez A: Co-expression of Mac-1 and p150,95 on CD5+ B cells. Structural and functional characterization in a human chronic lymphocytic leukemia. European Journal of Immunology 1988, 18:1131-1134.

37. McFarland HI, Nahill SR, Maciaszek JW, Welsh RM: CD11b (Mac-1): a marker for CD8+ cytotoxic T cell activation and memory in virus infection. Journal of Immunology 1992, 149:1326-1333.

38. Springer T, Galfre G, Secher DS, Milstein C: Mac-1: a macrophage differentiation antigen identified by monoclonal antibody. European Journal of Immunology 1979, 9:301-306.

39. Wright $S D$, Rao PE, Van Voorhis WC, Craigmyle LS, lida K, Talle MA, Westberg EF, Goldstein G, Silverstein SC: Identification of the C3bi receptor of human monocytes and macrophages by using monoclonal antibodies. Proc Natl Acad Sci USA 1983, 80:5699-5703.

40. Zarling JM, Kung PC: Monoclonal antibodies which distinguish between human NK cells and cytotoxic T lymphocytes. Nature 1980, 288:394-396.

41. Bjartmar C, Trapp BD: Axonal degeneration and progressive neurologic disability in multiple sclerosis. Neurotox Res 2003, 5:157-164.
42. Bjartmar C, Wujek JR, Trapp BD: Axonal loss in the pathology of MS: consequences for understanding the progressive phase of the disease. $J$ Neurol Sci 2003, 206:165-171.

43. Carpenter MB, Alling FA, Bard DS: Lesions of the Descending Vestibular Nucleus in the Cat. Journal of Comparative Neurology 1960, 114:39.

44. Shriver LP, Dittel BN: T-cell-mediated disruption of the neuronal microtubule network: correlation with early reversible axonal dysfunction in acute experimental autoimmune encephalomyelitis. American Journal of Pathology 2006, 169:999-1011.

45. Abromson-Leeman S, Ladell DS, Bronson RT, Dorf ME: Heterogeneity of EAE mediated by multiple distinct T-effector subsets. Journal of Neuroimmunology 2007, 192:3-12.

46. Bettelli E, Sullivan B, Szabo SJ, Sobel RA, Glimcher LH, Kuchroo VK: Loss of T-bet, but not STAT1, prevents the development of experimental autoimmune encephalomyelitis. Journal of Experimental Medicine 2004, 200:79-87.

47. Stromnes IM, Cerretti LM, Liggitt D, Harris RA, Goverman JM: Differential regulation of central nervous system autoimmunity by $T(H) 1$ and $T(H) 17$ cells. Nature Medicine 2008, 14:337-342.

48. Olson JK, Girvin AM, Miller SD: Direct activation of innate and antigenpresenting functions of microglia following infection with Theiler's virus. J Virol 2001, 75:9780-9789.

49. Neumann J, Sauerzweig S, Roenicke R, Gunzer F, Dinkel K, Ullrich O, Gunzer M, Reymann KG: Microglia cells protect neurons by direct engulfment of invading neutrophil granulocytes: A new mechanism of CNS immune privilege. Journal of Neuroscience 2008, 28:5965-5975.

50. Streit WJ: Microglia as neuroprotective, immunocompetent cells of the CNS. Glia 2002, 40:133-139.

51. Walton NM, Sutter BM, Laywell ED, Levkoff LH, Kearns SM, Marshall GP, Scheffler B, Steindler DA: Microglia instruct subventricular zone neurogenesis. Glia 2006, 54:815-825.

52. Ziv Y, Ron N, Butovsky O, Landa G, Sudai E, Greenberg N, Cohen H, Kipnis J, Schwartz M: Immune cells contribute to the maintenance of neurogenesis and spatial learning abilities in adulthood. Nature Neuroscience 2006, 9:268-275.

53. Iliev Al, Stringaris AK, Nau R, Neumann H: Neuronal injury mediated via stimulation of microglial toll-like receptor-9 (TLR9). Faseb Journal 2004, 18:412-414.

54. Kaushal V, Schlichter LC: Mechanisms of microglia-mediated neurotoxicity in a new model of the stroke penumbra. Journal of Neuroscience 2008, 28:2221-2230

55. Liu B, Gao HM, Wang JY, Jeohn GH, Cooper CL, Hong JS: Role of nitric oxide in inflammation-mediated neurodegeneration. Nitric Oxide: Novel Actions, Deleterious Effects and Clinical Potential 2002, 962:318-331.

56. Nikic I, Merkler D, Sorbara C, Brinkoetter M, Kreutzfeldt M, Bareyre FM, Bruck W, Bishop D, Misgeld T, Kerschensteiner M: A reversible form of axon damage in experimental autoimmune encephalomyelitis and multiple sclerosis. Nature Medicine 2011, 17:495-U135.

57. Waxman SG: Axonal conduction and injury in multiple sclerosis: the role of sodium channels. Nature Reviews Neuroscience 2006, 7:932-941.

58. Maskey D, Pradhan J, Kim HJ, Park KS, Ahn SC, Kim MJ: Immunohistochemical localization of calbindin D28-k, parvalbumin, and calretinin in the cerebellar cortex of the circling mouse. Neuroscience Letters 2010, 483:132-136.

doi:10.1186/1742-2094-9-7

Cite this article as: Lee et al.: IFN-gamma signaling in the central nervous system controls the course of experimental autoimmune encephalomyelitis independently of the localization and composition of inflammatory foci. Journal of Neuroinflammation 2012 9:7. 